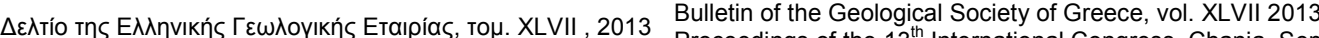
Proceedings of the $13^{\text {th }}$ International Congress, Chania, Sept.

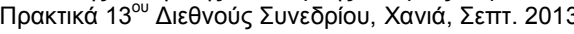
2013

\title{
DEVELOPMENT OF MULTI-CRITERIA DECISION SUPPORT SYSTEM (DSS) COUPLED WITH GIS FOR IDENTIFYING OPTIMAL LOCATIONS FOR SOIL AQUIFER TREATMENT (SAT) FACILITIES
}

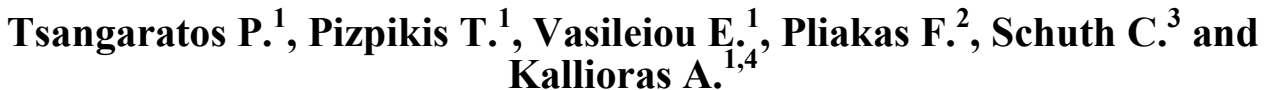 \\ ${ }^{I}$ National Technical University of Athens, School of Mining and Metallurgical Engineering, \\ Athens, 15780, Greece (ptsag@metal.ntua.gr) \\ ${ }^{2}$ Democritus University of Thrace, Department of Civil Engineering, Xanthi, 67100, Greece. \\ ${ }^{3}$ Technical University of Darmstadt, Institute of Applied Geosciences, Darmstadt, 64287, \\ Germany. \\ ${ }^{4}$ Helmholtz Centre for Environmental Research - UFZ, Leipzig, 04318, Germany.
}

\begin{abstract}
Managed Aquifer Recharge is a wide-spread well-established groundwater engineering method which is largely seen as an alternative potential major source for water and this conclusion becomes even more pronounced in semi-arid and/or arid areas, such as the Mediterranean Basin. The process of site selection for the installation of a MAR facility is of paramount importance for the feasibility and effectiveness of the project itself, especially when the facility will include the use of waters of impaired quality as a recharge source.

The main objective of this study is to present the developed framework of a multicriteria Decision Support System (DSS) that integrates within a dynamic platform: the main groundwater engineering parameters associated with MAR applications together with the general geographical features which determine the effectiveness of such a project. The proposed system will provide an advanced coupled DSS-GIS tool capable of handling local MAR-related issues -such as hydrogeology, topography, soil, climate etc., and spatially distributed variables -such as societal, economic, administrative, legislative etc., with special reference to Soil-AquiferTreatment technologies. The new SAT-selection tool in question is integrated in ArcGIS software -within a user friendly environment- where data can be processed and displayed using Arc tools for spatial analysis.

Key words: Managed Aquifer Recharge-MAR, Soil-Aquifer-Treatment-SAT, Decision Support System-DSS, Geographical Information Systems-GIS, groundwater management.
\end{abstract}

\section{Пврі́ $\eta \psi \eta$}

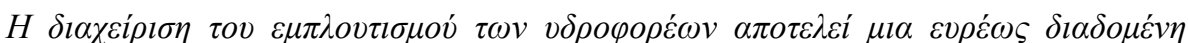

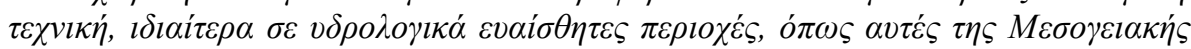

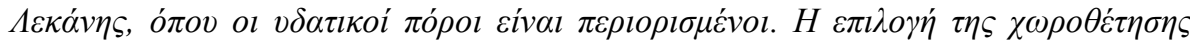

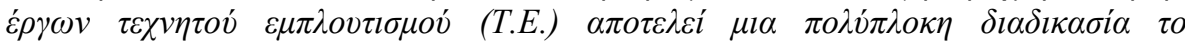

XLVII. No $2-789$ 


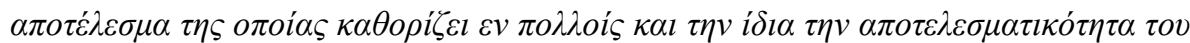

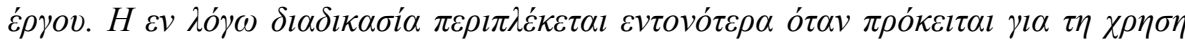

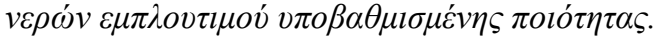

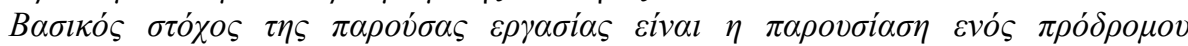

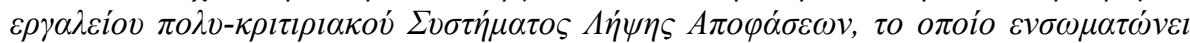

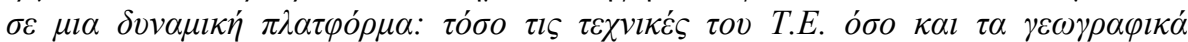

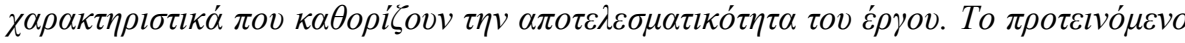

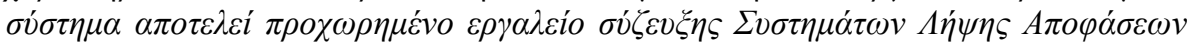

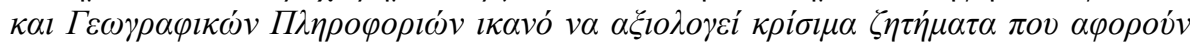

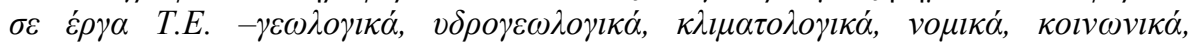

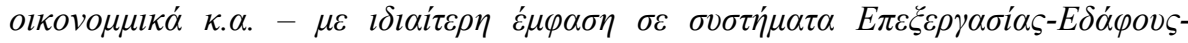

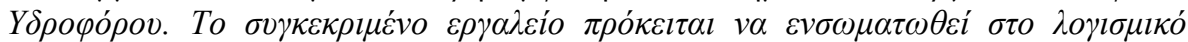

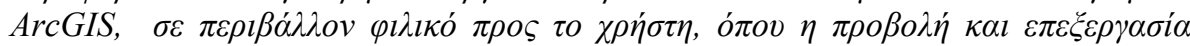

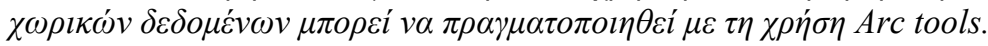

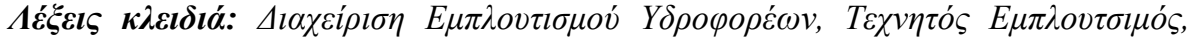

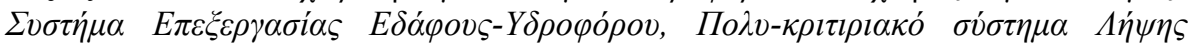

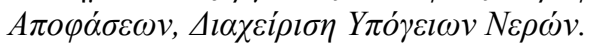

\section{Introduction}

Artificial recharge (AR) systems are engineered systems where surface water is put on or in the ground for infiltration and subsequent movement to aquifers to augment groundwater resources (Bower, 2002); while some of their most typical objectives include: (i) the minimization of seawater intrusion by forming a hydraulic barrier along the coast, (ii) the demonstration of aquifers as effective underground water reservoirs, and, (iii) to improve the quality of the water through Soil-Aquifer-Treatment (SAT) or geo-purification. The type of system to be selected for artificial recharge of groundwater and how it should be designed and managed for optimum performance depends entirely on local conditions of soil, hydrogeology, topography, water availability (quality, continuous, or interrupted supply), and climate (Bower, 2004). Dillon (2005,) summarizes all available groundwater engineering techniques for Managed Aquifer Recharge (MAR): Aquifer Storage and Recovery (ASR); Aquifer storage transfer and recovery (ASTR) (Dillon et al., 2008); bank filtration; injection wells; dune filtration; infiltration ponds; percolation tanks; rainwater harvesting; Soil Aquifer Treatment (SAT); sand dams; underground dams; recharge releases.

SAT facilities are engineered synthesis of MAR and wastewater re-use and/or reclamation technology, renovating waters of impaired quality into indirect potable levels. Groundwater recharge with reclaimed municipal wastewater presents a wide spectrum of technical and health challenges that must be carefully evaluated prior to undertaking a project (Asano and Cotruvo, 2004). SAT systems typically remove essentially all suspended solids, biochemical oxygen demand (BOD), and pathogens (viruses, bacteria, protozoa, and helminthic eggs). Concentrations of synthetic organic carbon, phosphorous, and heavy metals are greatly reduced, while nitrogen can either be left in the water if needed as fertilizer for irrigation use or can be removed in the pretreatment process.

Within a site suitability problem, site selection is the outcome of a process, which evaluates a variety of needs for the prospective location and the suggestion of an area on the basis of a proper assessment of the land. The process described above is the main objective and the prime prerequisite in an AR system scheme while the performance of AR scheme clearly depends on the ability of the decision makers to collect and analyze the proper geographic data. However, large number of parameters and the extent of their interrelationships among these parameters cause difficulties in decision making, as complex regional hydrological and hydrogeological characteristics make site selection for AR systems a very demanding task.

$\underline{\text { XLVII. No } 2-790}$ 
The complexity in which the spatial problem results, may require processing at a level that exceeds a decision maker's cognitive ability. The role of Geographical Information System (GIS) and Multi Criteria Decision Analysis (MCDA) techniques is to support the decision maker in achieving greater effectiveness and efficiency of decision making while solving spatial decision problems. In addition the combination of GIS and MCDM provides the decision maker with support in all stages of decision making, that is, in the preparation stage (collecting and storing data), design, and choice phases of the decision making process. A number of criterion weighting procedures based on the judgment of decision makers have been proposed in the multi - criteria decision bibliography. Some of the most popular procedures include: ranking, rating, pair-wise comparison and trade-off analysis (Malczewski, 1999). Each method differs in terms of their accuracy, degree of easiness to use, understanding and theoretical foundation and to choice the best for our problem requires discussion, field verification and iterative modifications. In this study the pair-wise comparison method was used in the context of the Analytic Hierarchy Process (AHP) in order to identify suitable sites for SAT applications in Attica Prefecture within a GIS tool. The product can be seen as an effective tool which can be used by water authorities and/or water utility companies for the integrated management of municipal wastewater.

\section{Materials and Methods}

\subsection{Framework}

Decision-making can be regarded as a process, which helps in the selection of a course of actions among several alternative scenarios. Every decision-making process produces a final choice (Reason, 1990), while the proposed framework usually involves three main phases: (a) Problem Definition Process (PDP), (b) Constraint Mapping Process, (CMP), (c) Suitability Mapping Process (SMP).

\subsubsection{Problem Definition Process}

The problem definition process is the first and most essential process that involves recognition and definition of the decision problem. In water resources planning and management, SAT has proved to be an effective countermeasure to water scarcity problems. In order to identify the suitable sites and produce a preliminary suitability map, one has to integrate Multi Criteria Decision Analysis (MCDA) techniques into a Geographical Information System (GIS). MCDA combines appropriate technical, economical, social and environmental criteria and weights them with respect to their importance to SAT; while GIS provides spatial analysis of the aforementioned criteria. Several MCDA techniques were used in many fields for site selection and land allocation; ELECTRE, PROMETHEE, AHP, TOPSIS, AIM, etc. (Gilliams et al., 2005; Gomez and Barredo, 2005; Zhong-Wu et al., 2007). However, only few of them are integrated into GIS (Gomez and Barredo, 2005; Marinoni, 2004), among which the Analytic Hierarchy Process (AHP) is the most widely applied. AHP was established by Thomas Lorie Saaty in the 1970s (Saaty, 1980) and used to determine the priority of different decision alternatives via pairwise comparisons with respect to common criteria.

\subsubsection{Constraint Mapping Process}

A constraint map represents the limitations of the value that attributes and decision variables may assume. In this phase the main objective is to avoid conflicts in decision-making. Areas of interest to other planning projects or which are non-feasible for SAT implementation are excluded from further analysis. The developed constraint map serves as a "mask" for the next process of SMP.

\subsubsection{Suitability Mapping Process}

The next step is to set the evaluation criteria; a step that involves specifying:

- A comprehensive set of objectives that reflect all concerns relevant to the decision problem. 
- Measures for achieving those objectives; so-called attributes.

The degree to which the objectives are met, as measured by the attributes, is the basis for comparing alternatives. The evaluation criteria are associated with geospatial entities and relationships among geospatial entities and therefore can be represented in the form of thematic or data layer maps. The information about the relative importance of the criteria is usually obtained by assigning a weight to each criterion. The value of the weight represents its importance relative to other criteria under consideration, in which the larger the value, the more important the criterion in the overall utility (Malczewski, 1999). The next section (2.2) provides in more detail a description about the methodology followed during the Suitability Mapping Process.

\subsection{Step by Step SMP}

The methodology involves the following steps: (a) select essential criteria of suitability to SAT, (b) use GIS to manage the related data layers, (c) develop a decision hierarchy structure, (d) standardise each criterion, (e) identify priorities for each of the decision criteria, (f) estimate the Suitability Index $\left(\mathrm{S}_{\mathrm{i}}\right)$ and $(\mathrm{g})$ extract best-suitable sites based on their $\mathrm{S}_{\mathrm{i}}$ value.

The first critical step during the phase of SMP is the selection of the appropriate and relevant surface, subsurface, spatial and non-spatial data such as geological maps, geomorphological, lineaments, slope inclination and slope orientation maps, land use cover, road infrastructure, power lines, proximity to water source and groundwater pollution. The next step is to convert all the data layers into a common scale, a process called standardization. It is of paramount importance that the classes of each factor have to be standardized into a common scale. The rating of the classes within each factor is based on the relative importance of each class obtained from expert knowledge or statistical assumptions. To standardize the classes to a uniform rating scale, Equation 1 is be applied.

\section{Equation 1 - standardized rank values}

newValue $=\frac{(\text { oldValue }-\min (\text { oldValue })}{\max (\text { oldValue })-\min (\text { oldValue })} *(\max ($ newRange $)-\min ($ new $($ Range $))+\min ($ newRange $)$

Where, $\min ($ newRange $)=1$, and $\max ($ newRange $)=3$.

As already discussed the AHP method was used in this study to systematically assign preferences based on Saaty's proposal (Saaty, 2000). The method assists in determining the importance of each of the selected factor in the SMP. The method involves six essential steps: (i) define the unstructured problem, (ii) develop the AHP hierarchy, (iii) pair wise comparison, (iv) estimate the relative weights, (v) check the consistency and (vi) obtain the overall rating. The AHP reduces the complexity of a decision problem to a sequence of pair-wise comparisons, which are synthesized in an interaction matrix. The AHP method constructs a hierarchy of decision criteria and through the pair-wise comparison of each possible criterion pair a relative weight for each decision criterion is produced. Each comparison is a two-part question determining which criterion is more important, and how much more important, using a numerical relational scale (Table 1).

The next phase is to combine all the weighted factors by using the Weighted Linear Combination (WLC) method in order to obtain the Suitability Index. WLC is one of the widest known and most commonly used MCDA methods (Malczewski 1999, Ayalew et al. 2005). The method involves multiplying the weight value assigned for each factor by the standardized rank values given to each class and numerically added according to Equation 2 in order to produce the Suitability Index Map $\left(\mathrm{S}_{\mathrm{i}}\right)$. Each pixel of the final $\mathrm{S}_{\mathrm{i}}$ map, obtains a value that ranges between 0.1 and 1 , whereas 0.1 corresponds to the most unsuitable setting and 1 corresponds to the most suitable. 
Table 1 - Scale of importance between two parameters in AHP (Saaty, 2000).

\begin{tabular}{|l|l|l|}
\hline Scale & Intensity of importance & \multicolumn{1}{c|}{ Definition } \\
\hline 1 & Equally & Two activities contribute equally to the Objective \\
\hline 3 & Moderately & $\begin{array}{l}\text { Experience and judgment slightly to moderately } \\
\text { favour one activity over another }\end{array}$ \\
\hline 5 & Strongly & $\begin{array}{l}\text { Experience and judgment strongly or essentially } \\
\text { favour one activity over another }\end{array}$ \\
\hline 7 & Very strongly & $\begin{array}{l}\text { An activity is strongly favoured over another and } \\
\text { its dominance is showed in practice. }\end{array}$ \\
\hline 9 & Extremely & $\begin{array}{l}\text { The evidence of favouring one activity over an- } \\
\text { other is of the highest degree possible of an affir- } \\
\text { mation. }\end{array}$ \\
\hline $2,4,6,8$ & Intermediate values & $\begin{array}{l}\text { Used to represent compromises between the } \\
\text { references in weights } 1,3,5,7 \text { and } 9\end{array}$ \\
\hline
\end{tabular}

Equation 2 - Suitability Index $\left(\mathrm{S}_{\mathrm{i}}\right)$ for each pixel

$$
S_{p i}={ }_{j=1}^{n} F W_{j} \quad C_{b j} f_{j}
$$

where pi the $\mathrm{i}^{\text {th }}$ pixel, $\mathrm{FW}_{\mathrm{j}}$ the weight of the $\mathrm{j}^{\text {th }}$ factor and $\mathrm{cf}_{\mathrm{j}}$ the standardized ratings of class $\mathrm{k}^{\text {th }}$ of the $\mathrm{j}^{\text {th }}$ factor.

\section{Case Study Application}

\subsection{Problem Definition - General Characteristic of the Study Area}

The Region of Attica covers an area of $3,207 \mathrm{~km}^{2}$, containing more than half the population of Greece, surrounded by (1,413 m), Kitheronas (1,400 m), Penteli (1,108 m), Hymettus (1,025 m) and Aegaleo (469m). The basin of Attica, Thriasio plain, Mesogea, Megara and the coastal zone of Marathonas and Nea Makri, are the main parts of the lowlands with a mean elevation of $115 \mathrm{~m}$. Attica Water District involves the entire Region of Attica, the islands of Aegina, Salamina and Makronisos and small parts of Sterea Ellada and Peloponnese (IGME, 2010).

The climate of the study area is Mediterranean continental, with relatively mild wet winters and hot-dry summers. The average temperature is $16-18^{\circ} \mathrm{C}$ (Koutsogiannis, 2007). The average annual precipitation is $400 \mathrm{~mm}$, ranging from less than $400 \mathrm{~mm}$-within the south coastal areas- to 600 $\mathrm{mm}$ at the mainland and 1,000 $\mathrm{mm}$ on the mountainous zones, the highest values observed in the mountain Kitheronas and Parnitha (IGME, 2010). The two main rivers are Illissos and Kifissos, which in the urbanized areas have been channelized, discharging into Saronikos Gulf.

Attica consists of two geological units, the basement with rock formations -Paleozoic to Upper Cretaceous (marbles, dolomites, limestones, phyllites, schists and conglomerates of flysch)- and the clastic cover of Neogene and Quaternary deposits of the Plio-Pleistocene (sands, gravels, conglomerates, marls, clays, sandstones, lacustrine). The lithological formations have been the effect of successive tectonic movements and deep erosion in both the vertical and the horizontal.

Permeable geological formations cover a significant amount of the total area; with karstified limestones being the major ones, covering mainly the eastern and western part of the region. The 
total water availability is app. $449 \mathrm{hm}^{3}$ and this amount consists of $259 \mathrm{hm}^{3}$ surface water and 190 $\mathrm{hm}^{3}$ groundwater (Koutsogiannis, 2007). Three major aquifer systems are developed in Attica region: a) the karst aquifer systems -at the eastern and western parts-, b) the aquifer systems which are composed of unconsolidated materials -mainly present in coastal plain areas-, and c) the aquifer systems present in fractured formations.

Figure 1, shows the geographical location of the study area, including the morphological relief as well as the locations of the Wastewater Treatment Plants (WWTP) of Athens Water Supply \& Sewage Co SA (EYDAP). The number and location of WWTP facilities were considered as one of the most important parameters taken into account for the DSS, as they involve the major source of recharge water for the SAT systems.

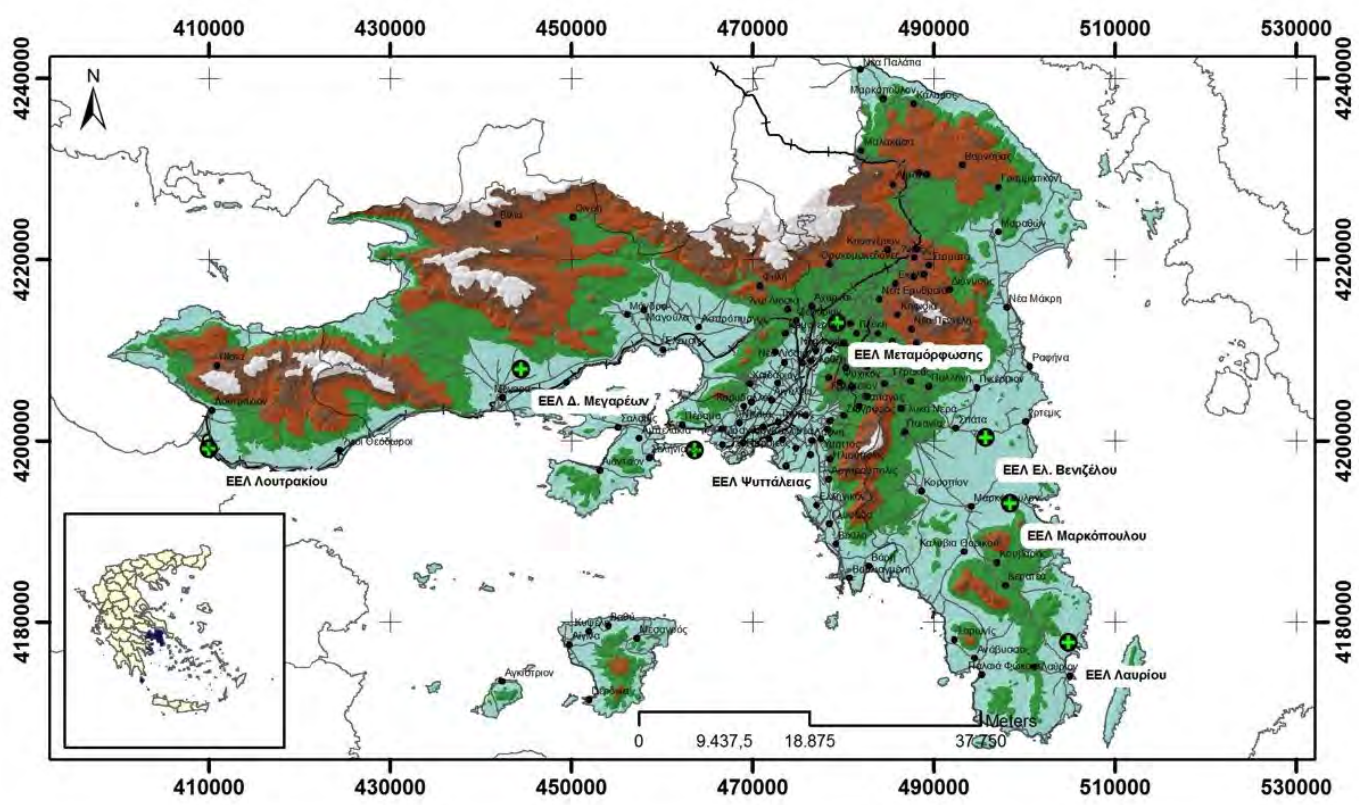

Figure 1 - Study area.

\subsection{Selecting the Appropriate Criteria}

Geology plays a very important factor for SAT, since it depicts the content of a large part of the vadose zone. In general, suitable sites should present a very low clay fraction in order to fulfil high hydraulic conductivity conditions and perform good complementary wastewater purification (Anane et al., 2008).

Depth to water table is a technical criterion of ample importance as it represents the thickness of the vadose zone in which the treated wastewater will undergo appropriate purification processes before it percolates in the saturated zone. The unsaturated layer should be thicker than $5 \mathrm{~m}$ (Asano et al., 2007) to enhance SAT, and to avoid any chance of contaminating the underlying aquifer.

Considering the topographic characteristics and more specifically the slope values, the steeper the surface profile appears the less suitable for aquifer recharge it is. Suitable areas for SAT are those with slope ranging from flat to $15^{\circ}$. Higher slopes increase runoff and soil erosion and lower slope indicate areas of high priority (EPA, 2004). The slope thematic layer was derived from Shuttle Radar Topography Mission Digital Elevation Model (SRTM DEM) 90m - resolution after projecting from UTM to EGSA '87. In general the existing land use of an area provides information about the land availability for implementing SAT. In urban areas or of industrial use 
the implementation is not - feasible. As stated by EPA (2004) the main criteria concerning the economic criteria should be the transport distance from the WWTP to the potential application site, which should not exceed $8 \mathrm{~km}$, and also the difference in elevation with WWTP level.

\subsection{Constraint Mapping Process}

Alternatives that do not meet the constraints are referred to as non-feasible or unaccepted. Under conjunctive screening an alternative is accepted if it meets specified standards or thresholds for all evaluation criteria. The study takes into consideration four constraint criteria: (a) protective areas, (b) distance to groundwater pollution source, and (c) land use cover. For each constraint criterion a threshold value is assigned in order to produce the constraint map (Table 2).

Table 2 - Land use types for MAR Constraint Mapping Process

\begin{tabular}{|l|l|l|}
\hline \multicolumn{2}{|c|}{ Constraint Criteria } & Threshold value \\
\hline Land use types & $\begin{array}{l}\text { Permanent crops, natural vegeta- } \\
\text { tion, rivers }\end{array}$ & Feasible \\
\hline & $\begin{array}{l}\text { Agricultural areas, irrigated areas, } \\
\text { quarries, urban areas }\end{array}$ & Non- feasible \\
\hline Proctective areas & Natura 2000, etc. & Non- feasible \\
\hline $\begin{array}{l}\text { Distance to groundwater } \\
\text { pollution source }\end{array}$ & $>500 \mathrm{~m}$ & Feasible \\
\hline & $<500 \mathrm{~m}$ & Non- feasible \\
\hline
\end{tabular}

The process involves the preparation of the final constraint map that is the product of the sum of each individual constraint map. Figure 2 shows the constraint thematic layers and the final constraint map.

\subsection{Suitability Mapping Process}

In order to rank the suitability of a given study area, a weight for each criterion is assigned. Weighting expresses the criterion degree of relevance or preference relatively to the other criteria. The methodology followed for SMP proceeds in weighting through the pair-wise comparison between the elements for each hierarchical level (Saaty, 1980). Table 3 shows the produced pairwise matrix for the main decision criteria, while Figures 3 to 5 show the three main thematic layer criteria, namely: (a) hydrolithological characteristics, (b) aquifer depth and (c) slope inclination.

Figure 3, shows the spatial distribution of the suitability criteria based on the hydrolithological characteristics of the study area. Three main categories were used, based on the geological formations present, with unconsolidated formations assigned as posing the most suitable conditions.

Figure 4 presents the depth to groundwater table, i.e. the thickness of the unsaturated zone within the major unconsolidated aquifer bodies of Attica, where SAT can be potentially applied. It is considered as being one of the most important suitability criteria for SAT site selection because the necessary treatment is obtained by filtration as the wastewater percolates through the vadose zone (with a critical thickness of at least $5 \mathrm{~m}$ ), and then some distance laterally through the aquifer. 

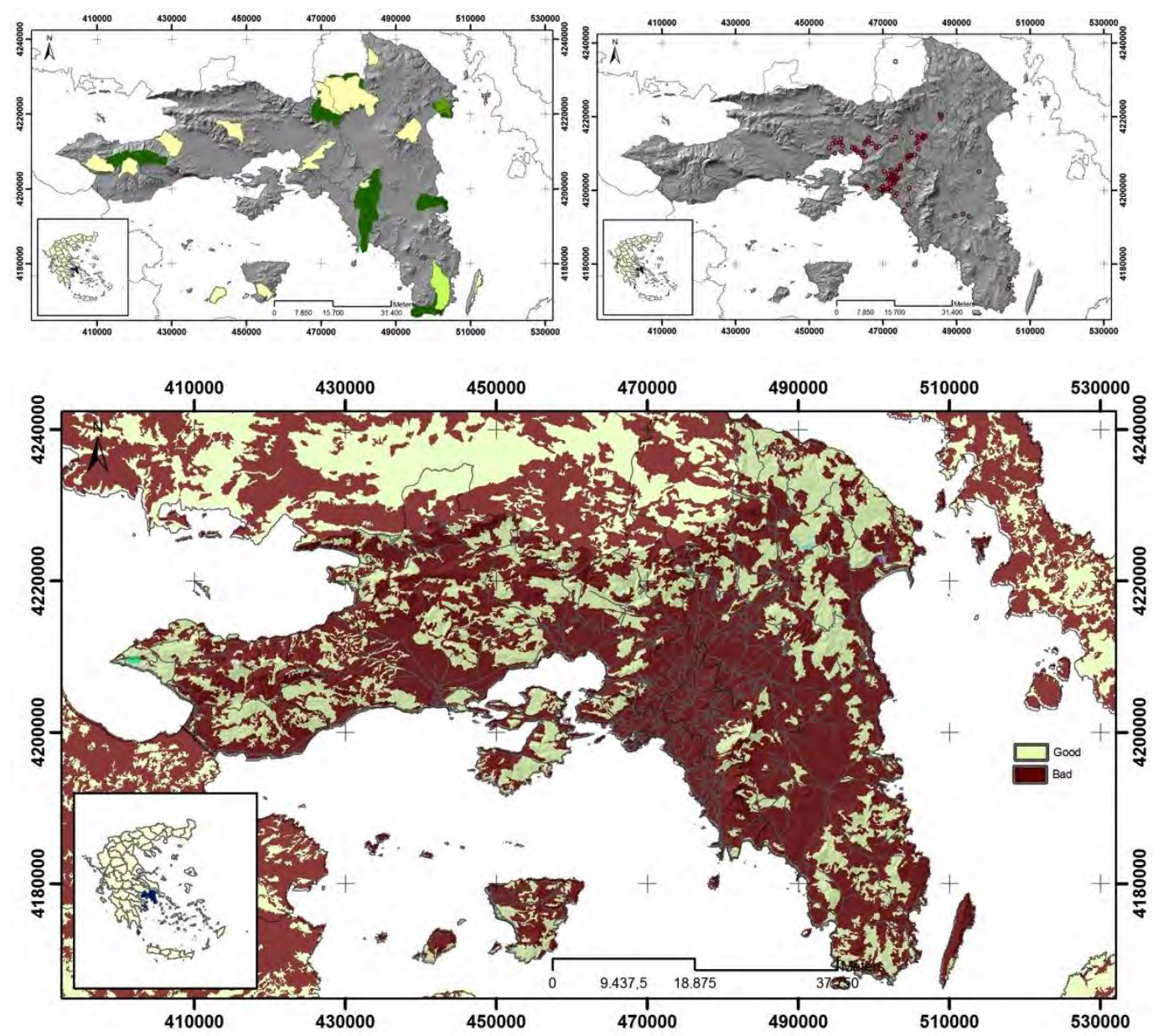

Figure 2 - Constraint criteria a. protected areas, b. industries, c. land use.

Table 3 - Pair-wise comparison matrix for evaluating the relative importance of the selected criteria for SAT.

\begin{tabular}{|l|l|c|l|l|l|l|}
\hline & F1 & F2 & F3 & F4 & F5 & w \\
\hline F1 & 1 & 1 & 5 & 7 & 9 & 0.398 \\
\hline F2 & 1 & 1 & 5 & 7 & 9 & 0.398 \\
\hline F3 & $1 / 5$ & $1 / 5$ & 1 & 3 & 4 & 0.112 \\
\hline F4 & $1 / 7$ & $1 / 7$ & $1 / 3$ & 1 & 3 & 0.059 \\
\hline F5 & $1 / 9$ & $1 / 9$ & $1 / 4$ & $1 / 3$ & 1 & 0.033 \\
\hline$\lambda \mathbf{m a x}$ & 5.1845 \\
\hline CI & \multicolumn{7}{|l|}{0461} \\
\hline CR & \multicolumn{7}{|l|}{} \\
\hline
\end{tabular}

F1: Hydrolithological characteristics, F2: Aquifer Depth, F3: Slope Inclination, F4: Distance from Residential Centres, F5: Distance from WWTP. 


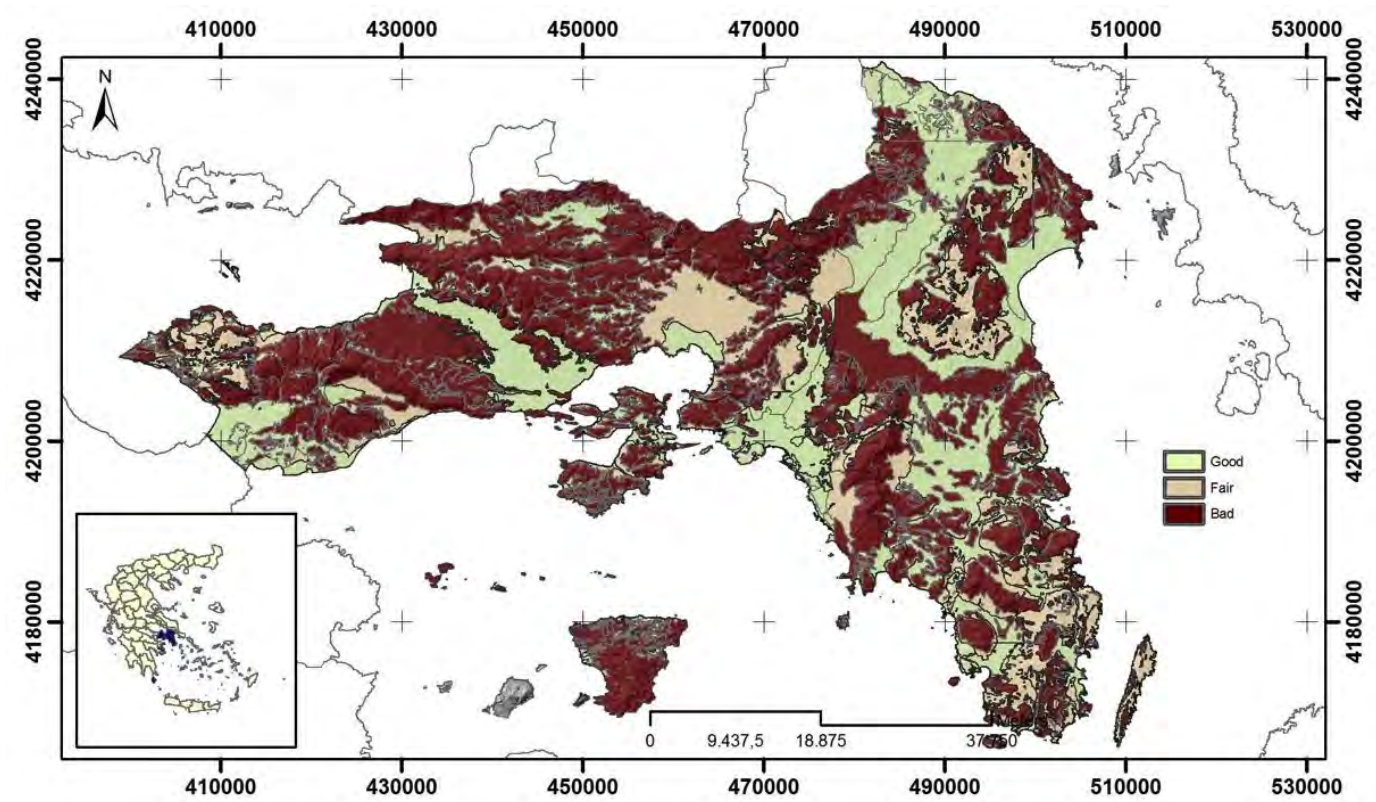

Figure 3 - Hydrolithological characteristics.

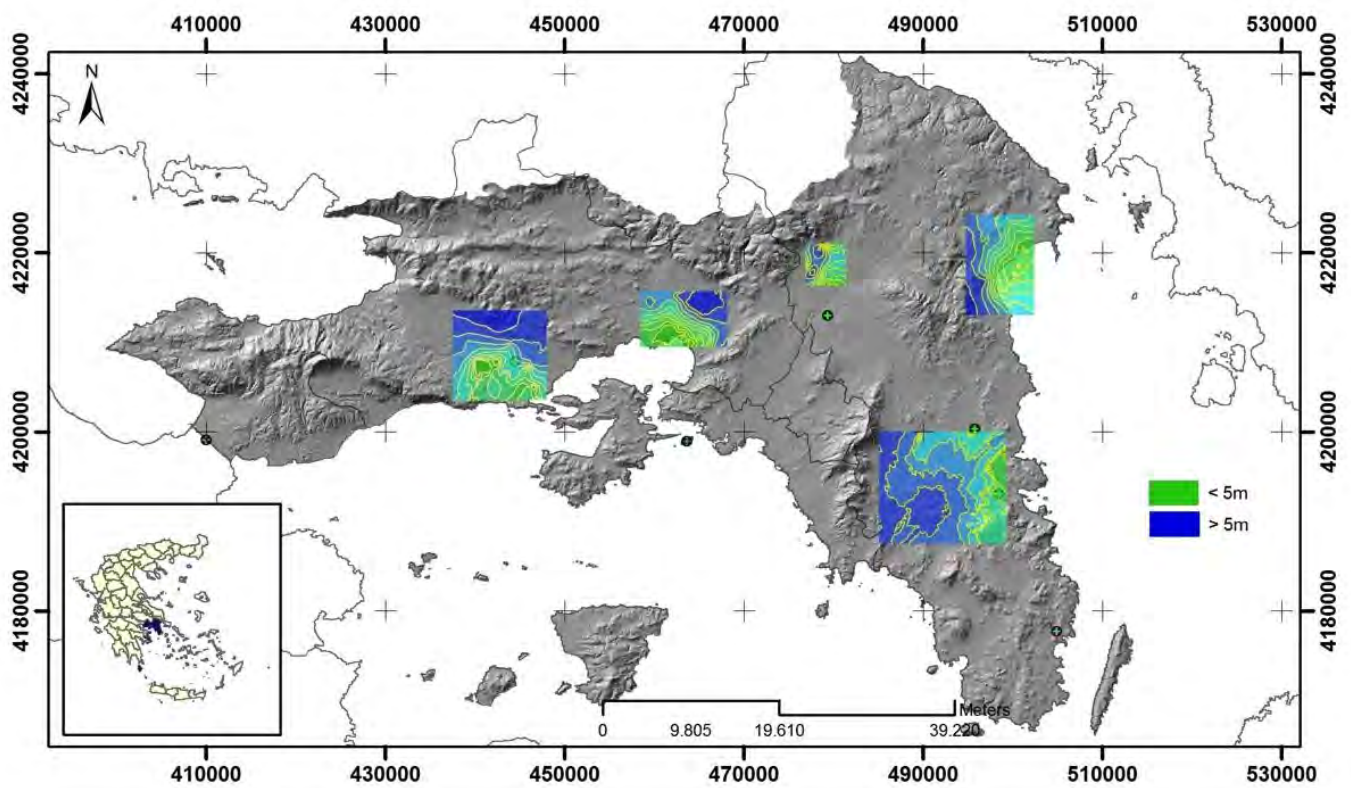

Figure 4 - Unsaturated zone thickness.

Figure 5 shows the distribution of slope inclination for the study area of Attica. Suitable areas for SAT are those with slope ranging from flat to $15^{\circ}$, while higher slopes increase runoff and soil erosion and lower slope indicate areas of high priority (EPA, 2004). Additionally, the lower the slopes, the most feasible the construction works during the basins preparation phase.

Figure 6 shows the final suitability map, and is produced after the synthesis of all the aforementioned suitability maps. Since SAT systems, require a source of reclaimed wastewater, final suitability map also contains the locations of the WWTP of EYDAP, highlighting the radius of optimal distance ( $8 \mathrm{~km}$ from the SAT facilities).

XLVII, No $2-797$ 


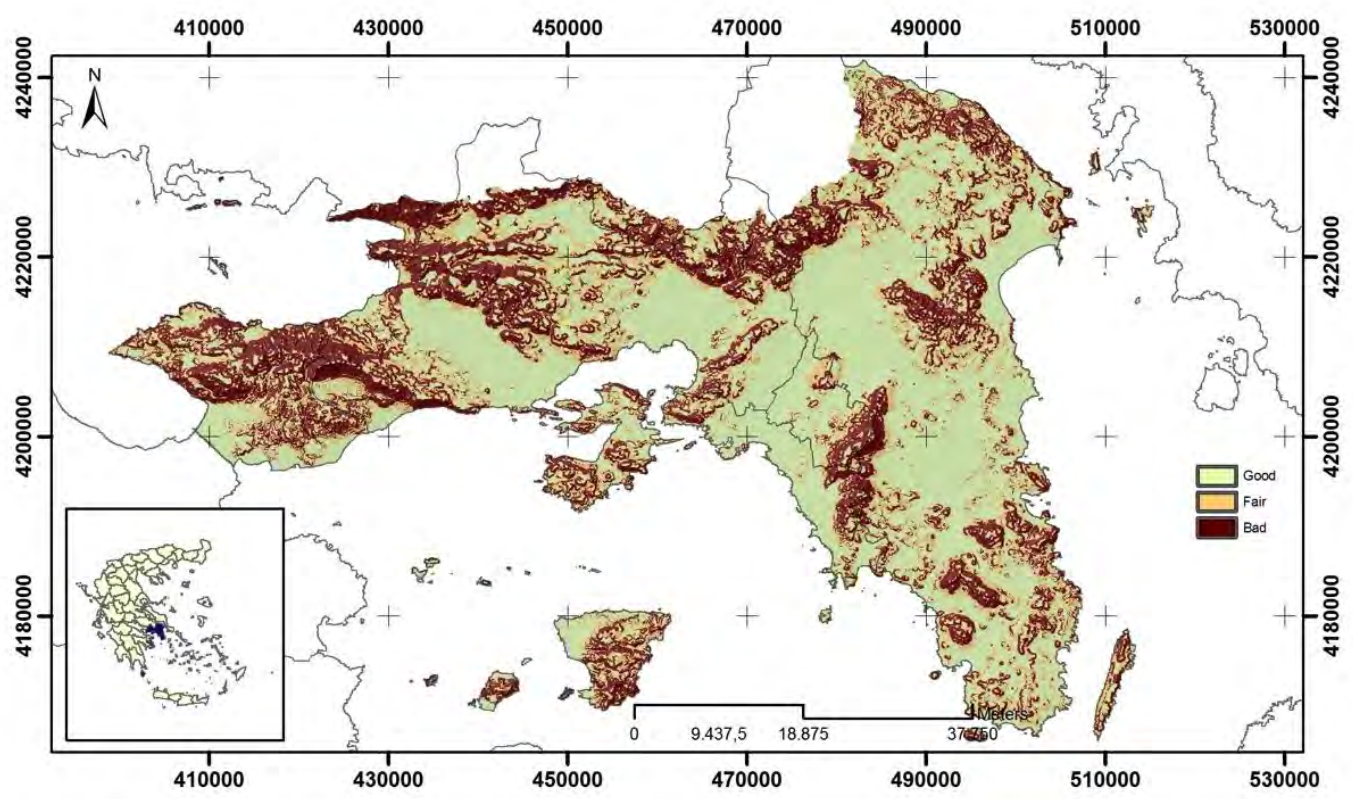

Figure 5 - Slope Inclination.

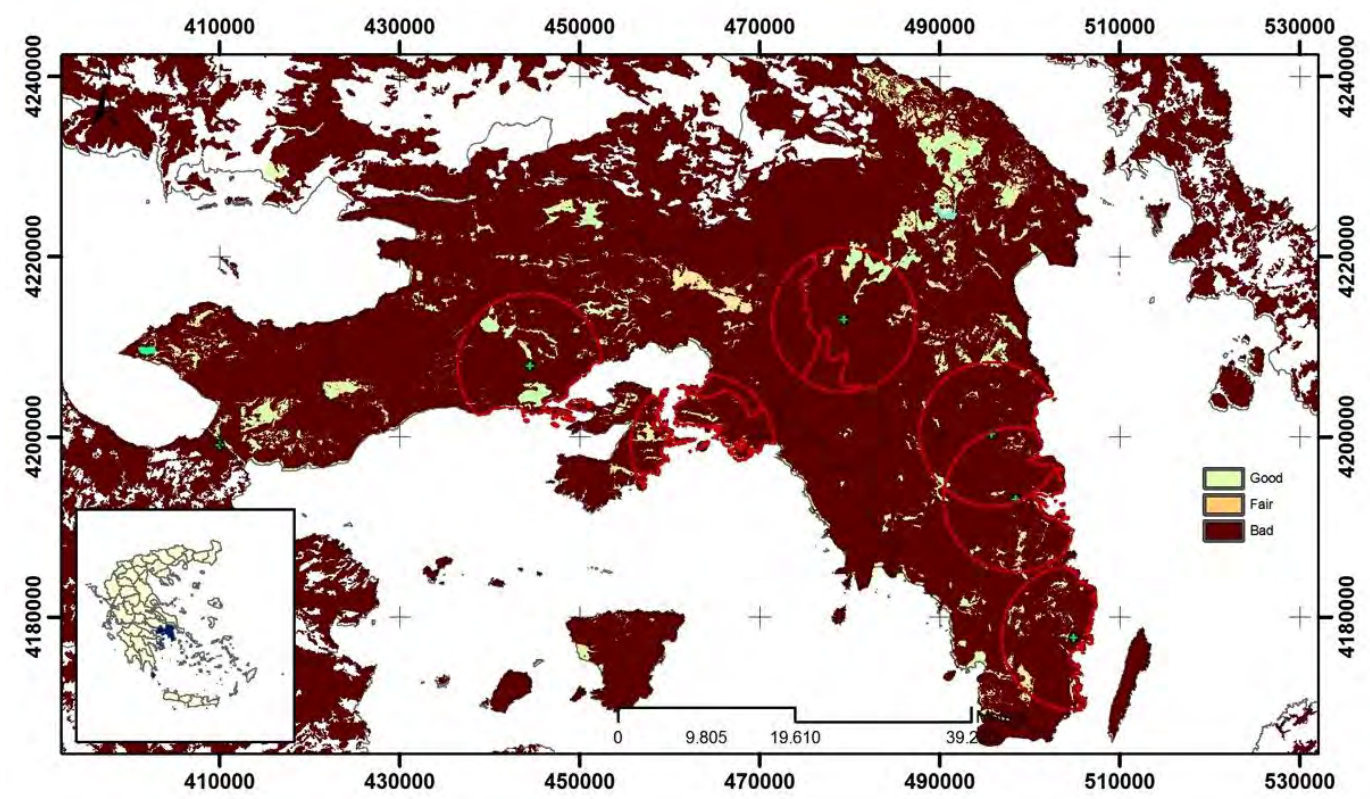

Figure 6 - Final suitability map. 


\section{Conclusions}

SAT is a cost-effective natural wastewater treatment and reuse technology, while Abel et al., (2012) quote that it is an environmentally friendly technology that does not require chemical usage and is applicable to both developing and developed countries. Through the use of innovative analytical tools, the removal/transformation of wastewater effluent organic matter (EfOM) have been tracked through SAT systems (Amy and Drewes, 2007).

In the present study, a single-objective AHP integrated with a GIS was carried out to identify potential sites for SAT installations in Attica Region. Major criteria were selected, taking into account hydrolithological settings, unsaturated zone thickness, slope inclination, and economic aspects related to the proximity of the WWTP with the potential SAT locations and the difference of elevation between the suitable area and the WWTP. Hydrolithological characteristics and aquifer depth have been found to be the most significant factors, as they are directly related to the geopurification processes during downward effluent filtration.

Site selection analysis involves a great number of objectives, criteria, alternatives and decision parameters, resulting in a complex decision environment. The developed framework promotes clear thinking and better understanding of the spatial problem of Aquifer Recharge together with reducing errors in importance judgement. One of the advantages of the methodology it that it also allows checking the consistency to the user's input weight for each criterion.

A final composite Suitability map of the study area is obtained calculating the $\mathrm{S}_{\mathrm{i}}$ for each pixel (i), according to equation 2 (Figure 6). The map is reclassified into 3 classes, good fair and bad. Since most of the study area involves mountainous zones and highly urbanized areas, the spatial distribution of locations preferable for SAT facilities are quite limited for the study area.

This work can be considered as a valuable managerial tool that technically supports the decision makers for integrated water resources management. Further developments could be achieved by multi objectives analysis, including other types of artificial recharge systems such as shallow or deep injection wells, induced recharge, artificial wetlands, infiltration trenches etc.

\section{References}

Abel C.D.T., Sharma S.K., Malolo Y.N., Maeng S.K., Kennedy M.D., Amy G.L. 2012. Attenuation of Bulk Organic Matter, Nutrients (N and P), and Pathogen Indicators During Soil Passage: Effect of Temperature and Redox Conditions in Simulated Soil Aquifer Treatment (SAT), Water Air Soil Pollution, 223, pp. 5205-5220.

Amy G., and Drewes J. 2007. Soil Aquifer Treatment (SAT) as a Natural and Sustainable Wastewater Reclamation/Reuse Technology: Fate of Wastewater Effluent Organic Matter (EfOM) and Trace Organic Compounds, Environ Monit Assess, 129, pp. 19-26.

Anane M., Kallali H., Jellali S. and Ouessar M. 2008. Ranking suitable sites for Soil Aquifer Treatment in Jerba Island (Tunisia) using remote sensing, GIS and AHP-multicriteria decision analysis, Int. J. Water, Vol. 4, Nos. 1/2, pp.121-135.

Asano T. and Cotruvo J.A. 2004. Groundwater recharge with reclaimed municipal wastewater: health and regulatory considerations, Water Research, 38, pp. 1941-1951.

Asano T., Burton F.L., Leverenz H. L. Tsuchihashi R. and Tchobanoglous G. 2007. Water Reuse, Issues, Technologies, and Applications, Metcalf \& Eddy | AECOM.

Ayalew L. and Yamagishi H., 2005. The application of GIS-based logistic regression for landslide susceptibility mapping in the Kakuda-Yahiko Mountains, Central Japan, Geomorphology 65(1-2), 15-31.

Bower H. 2002. Artificial recharge of groundwater: hydrogeology and engineering, Hydrogeology Journal, 10, pp. 121-142.

Bower H. 2004. Artificial recharge of groundwater: systems, design and management, Hydraulic Design Handbook, McGraw-Hill, Chapter 24, pp. 24.1-24.44. 
Dillon P. 2005. Future management of aquifer recharge, Hydrogeology Journal, 13, pp. 313-316.

Dillon P., Page D., Vanderzalm J., Pavelic P., Toze S., Bekele E., Sidhu J., Prommer H., Higginson S., Regel R., Rinck-Pfeiffer S., Purdie M., Pitman C. and Wintgens T. 2008. A critical evaluation of combined engineered and aquifer treatment systems in water recycling, Water Science and Technology, 57(5), pp. 753-762.

Environmental Protection Agency, E.P.A. - Guidelines for Water Reuse. EPA/625/R-04/108, U.S. Agency for Inter. Development, Washington, DC, USA, 2004

Gilliams S., Raymaekers D., Muys B. and van Orshoven J. 2005. Comparing multiple criteria decision methods to extend a geographical information system on afforestation, Computers and Electronics in Agriculture, Vol. 49, pp.142-158.

Gomez M. and Barredo J.L. 2005. Sistemas de Informacion Geograficay Evaluacion Multicriterio en la Ordenacion del Territorio, 2nd ed., RA-MA edition.

Institute of Geology \& Mineral Exploration, IGME, 2010. Recording and evaluating of groundwater hydrogeological characteristics and the aquifer systems of Greece, Athens, Internal Report.

Koutsogiannis D. 2007. Project plan of water resources management of the country, Ministry of Development - Directory of Water Dynamic and Natural Resources, Athens.

Malczewski J. 1999. GIS and Multicriteria Decision Analysis (John Wiley and Sons, New York, 1999).

Marinoni O. 2004. Implementation of the analytical hierarchy process with VBA in ArcGIS. Computers and Geosciences 30: 637-646, Amsterdam.

Saaty T.L. 1980. The Analytic Hierarchy Process, McGraw-Hill, New York.

Saaty T.L. 2000. Fundamentals of Decision Making and Priority Theory with the Analytic Hierarchy Process. 2nd Edn., RWS Publications, Pittsburg, USA.

Zhong-Wu L. Guang-Ming Z., Hua Z., Bin Y. and Sheng J. 2007. The integrated eco-environment assessment of the red soil hilly region based on GIS - a case study in Changsha City, China, Ecological Modelling, Vol. 202, pp.540-546. 